\title{
Experimental Study on Mechanical and Electrical Properties of PV-PVC Composites
}

\author{
Lanlan Zhang, ${ }^{1,2}$ Yingying Zhang $\mathbb{D}^{2,3}$ Meng $W u^{2,3}$ Junhao $X u,{ }^{2,3}$ and Jigang $X u e^{2,3}$ \\ ${ }^{1}$ School of Construction Engineering Management, Jiangsu Institute of Construction Technology, Xuzhou, Jiangsu 221116, China \\ ${ }^{2}$ China University of Mining and Technology, Xuzhou, Jiangsu 221116, China \\ ${ }^{3}$ Jiangsu Building Energy Conservation and Construction Technology Collaborative Innovation Center, Xuzhou, \\ Jiangsu 221116, China \\ Correspondence should be addressed to Yingying Zhang; zhangyingying_cumt@163.com
}

Received 26 January 2020; Revised 12 September 2020; Accepted 15 September 2020; Published 24 September 2020

Academic Editor: Gang Zhou

Copyright ( 2020 Lanlan Zhang et al. This is an open access article distributed under the Creative Commons Attribution License, which permits unrestricted use, distribution, and reproduction in any medium, provided the original work is properly cited.

\begin{abstract}
Based on BIPV, the idea of flexible amorphous silicon solar cell (PV) and PVC membrane composite was put forward. In this paper, the influence of composite mode and force form is mainly investigated. The mechanical and electrical properties of PVPVC composite under uniaxial and cyclic tension are obtained. The main results show that the tensile strength of PV-PVC composite is basically the same as that of PVC membrane. Compared with PVC membrane, the modulus of elasticity of PV-PVC composite under cyclic loading is significantly increased, while the residual strain and the area of hysteresis loop are significantly reduced. The difference in mechanical properties of different off-axis angles is significantly reduced. Under the stress level of common design strength of PVC membrane materials, solar cells can play a good photoelectric effect. This paper provides an important reference for the realization of membrane structure photovoltaic integration.
\end{abstract}

\section{Introduction}

With the rapid growth of the world population and the development of industrial technology, the demand for fossil energy is increasing $[1,2]$. This has caused great damage to the environment [3]. Therefore, BIPV has been developed as a new form of green energy-saving buildings [4-7]. BIPV is a technology that integrates photovoltaic systems into buildings. It has the characteristics of low energy consumption, sustainability, and high economic benefits [8-12]. Different from the traditional structure, the tensioned membrane structure is gentle and stretchable. It can be applied to large-span buildings, and the architectural styles are colorful [13-16]. This creates unique conditions for the integration of the flexible membrane solar cell and the tensioned membrane structure.

At present, most of the existing researches focus on the applicability and benefits of building photovoltaic integration. Rüther and Braun [17] and dos Santos [7], respectively, have evaluated the photovoltaic system of airport and residential buildings and concluded that the photovoltaic system can meet the requirements of low energy consumption of buildings. Hu et al. [18] have verified the applicability of the PV-ETFE air pillow system in winter. Zhang et al. [19-21] carried out a uniaxial tensile test and cyclic tensile test at different temperatures for coated fabric membrane materials, so as to carry out statistical analysis on its tensile strength, shear strength, and tear strength, and put forward the constitutive model of coated fabric membrane materials. However, the mechanical properties of coated fabric membranes are significantly affected by the load level in actual projects. Solar cells also inevitably bear the load from the film surface. The mechanical properties of composite materials after compounding are not yet clear. Therefore, it is of great significance to study the mechanical and electrical properties of PV-PVC composite under complex stress.

In this paper, based on the building system of the integration of flexible thin-film solar cells and membrane structures, PV-PVC composite materials are taken as the 
research object. The mechanical and electrical properties of PV-PVC composite under unidirectional and cyclic loading were studied by experiments. The variation of mechanical properties parameters before and after composite was investigated. The interaction mechanism of membrane material and solar cell was deeply analyzed.

\section{Experiment}

2.1. Uniaxial Tensile Test. The battery selected for the test is the flexible membrane solar cell produced by United Solar company of the United States. The membrane material selected is the PVC produced by Hailide company. In practical application, the flexible thin-film solar cell module is composed of many small battery strip units arranged in parallel along a certain direction. Therefore, the square test specimen composed of three cells and the rectangular test specimen composed of one cell are selected in the experiment.

According to the characteristics of flexible thin-film solar cell and PVC membrane surface, the high-strength adhesive was selected to composite the two materials. Based on the anisotropy of the material, a total of 7 off-axis compound angles of $0^{\circ}, 15^{\circ}, 30^{\circ}, 45^{\circ}, 60^{\circ}, 75^{\circ}$, and $90^{\circ}$ were designed. The planar size of the composite strip test specimen is $200 \mathrm{~mm} \times 50 \mathrm{~mm}$, and the two ends of the membrane material extend $50 \mathrm{~mm}$ as the clamping end, as shown in Figure 1. The square test specimen is compounded in two ways: the direction of the battery strip and the warp of the membrane material, and the direction of the battery strip and the weft of the membrane material. The plane dimension of the PV-PVC composite square specimen is $180 \mathrm{~mm} \times 180 \mathrm{~mm}$. Each group of the same test piece is required to be repeated 5 times.

In order to make further analysis, the experiments on tensile strength were carried out taking the four component materials, the finished product, and the film of the battery as the research objects. The test pieces are rectangular and square, as shown in Figures 2 and 3, respectively.

The uniaxial tensile test is carried out on the electronic universal tensile testing machine. The positive and negative poles of the solar cell are connected to a multimeter by wires. The halogen lamp is placed in the front of the solar cell so that the light is irradiated vertically on the front of the cell. The force-displacement curve of the specimen is obtained by obtaining the tensile sensor of the testing machine and the large deformation tester. At the same time, the output voltage of the specimen during the drawing process is recorded by using the multimeter. The layout of the test site is shown in Figure 4.

2.2. Uniaxial Cyclic Tensile Test. The materials for the cyclic tensile test are the same as those for the uniaxial tensile test. The test is also carried out on the electronic universal tensile testing machine. The uniaxial cyclic tensile test is loaded in a repeated triangular wave mode, as shown in Figure 5. Firstly, the specimen was stretched from 0 to the maximum stress value at a constant tensile rate of $20 \mathrm{~N} / \mathrm{s}$. Then the load is decreased at the same rate until the stress reaches the

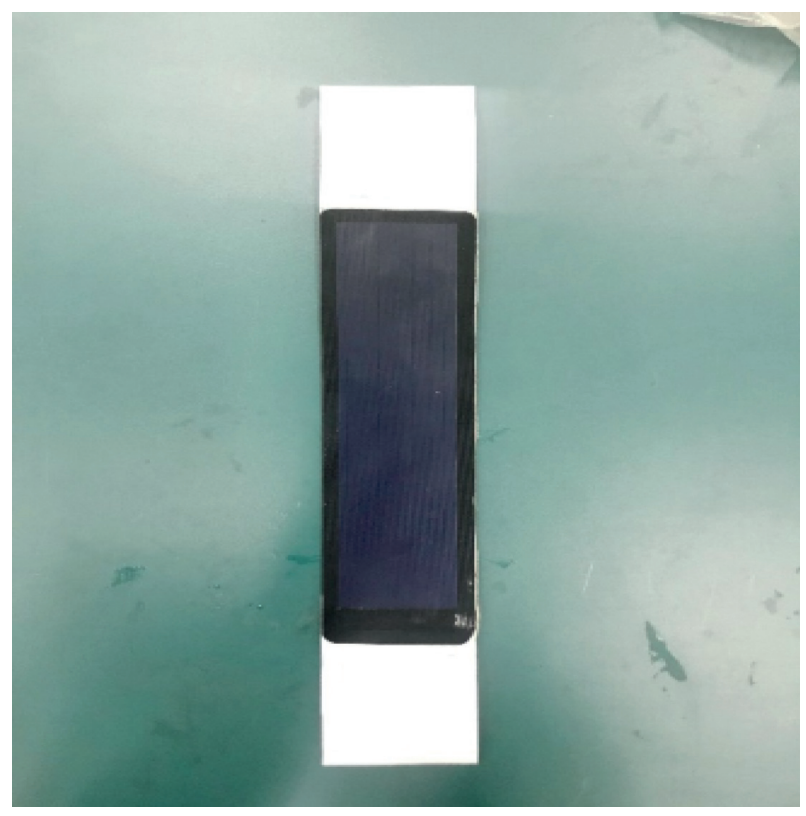

FIgURE 1: PV-PVC composite specimen.

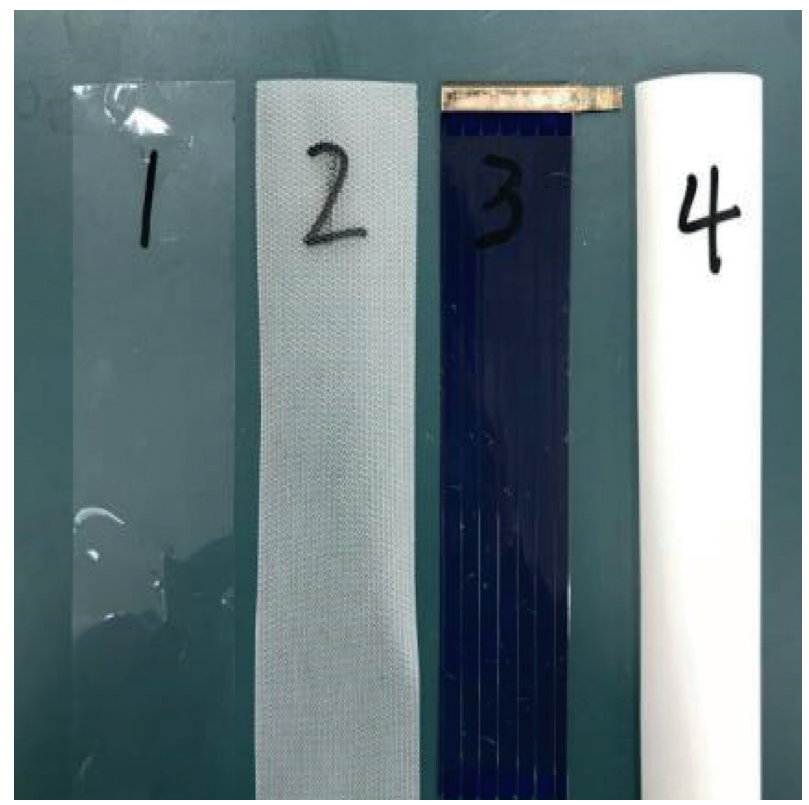

Figure 2: Composition material specimens.

minimum. The above steps are repeated 10 times. Considering the load range of membrane structure in practical application, the stress amplitude range is $3 \mathrm{kN} / \mathrm{m}$ to $16 \mathrm{kN} / \mathrm{m}$ for PVC and PV-PVC composite materials. In addition, two sets of tests of PVC and PV-PVC composite materials were designed for comparison.

\section{Results and Discussion}

\subsection{Uniaxial Tensile Test}

3.1.1. Mechanical and Electrical Properties. Figure 6 shows the stress-strain curve of each layer of flexible thin-film solar cell material and the complete rectangular specimen. The 


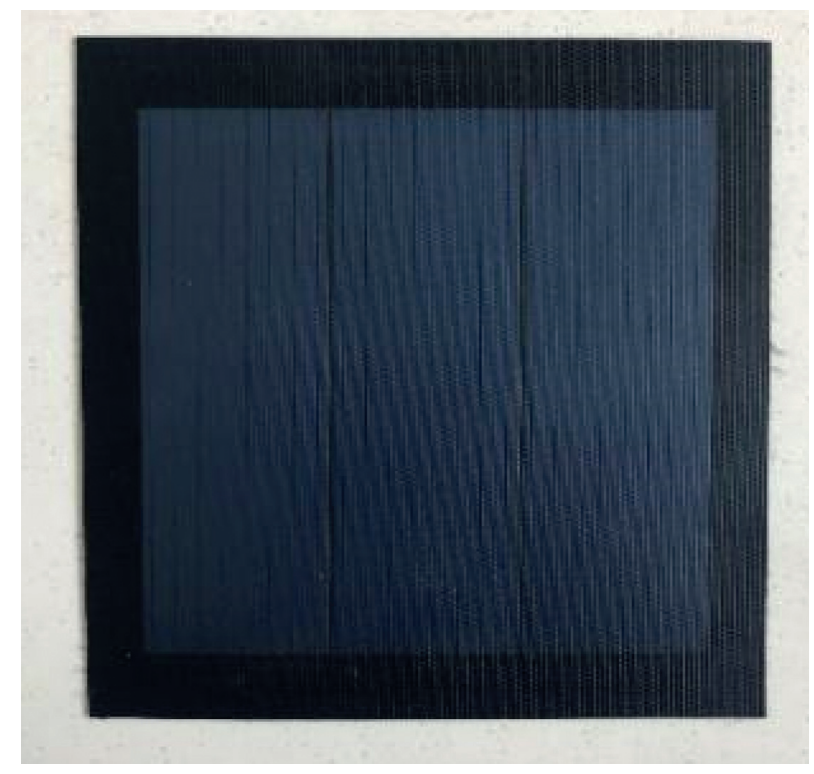

Figure 3: Finished battery specimen.

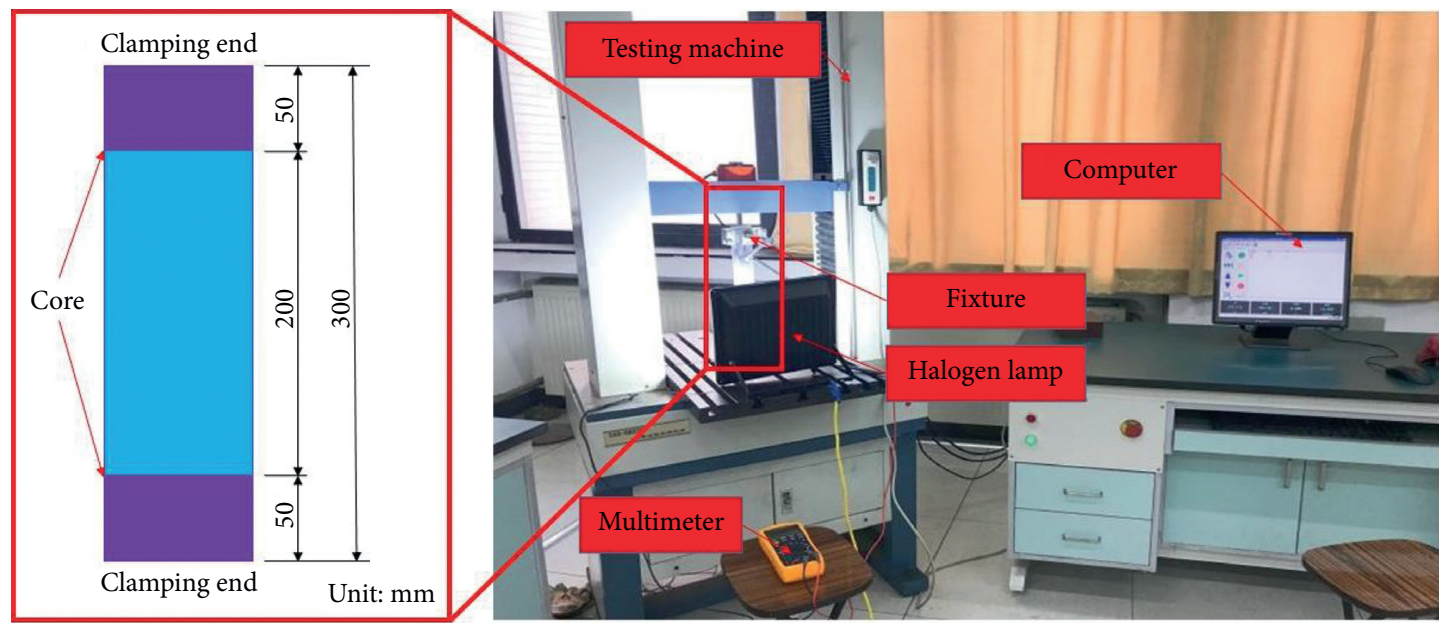

FIgURE 4: Test site layout.

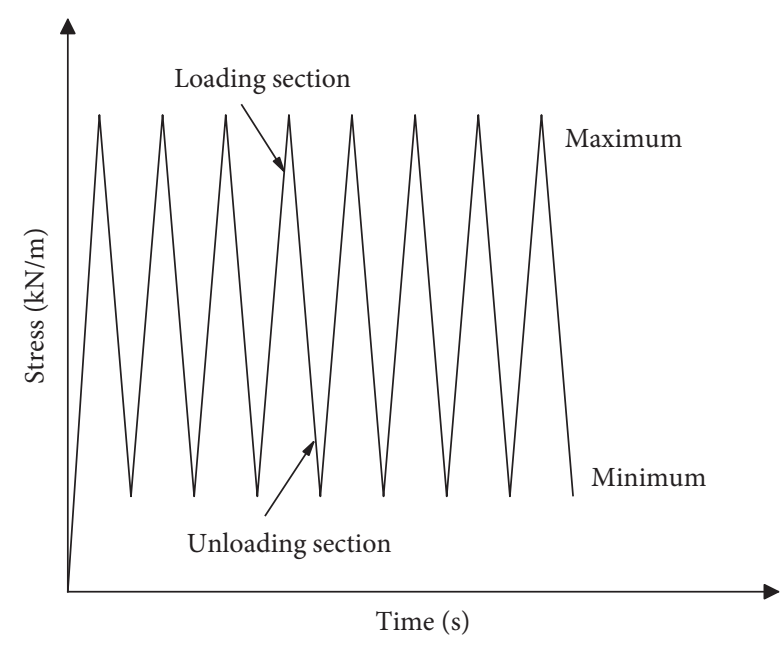

Figure 5: Cyclic tensile loading system. stress-strain curve of the second layer is similar to that of the first layer. It can be seen from Figure 6(b) that the tensile curve of the third layer material is basically the same as that of the complete solar cell finished product. It indicates that the mechanical properties of the flexible thin-film solar cell are mainly determined by the stainless steel substrate material of the core cell layer.

Figure 7 shows the tensile stress-strain curve of the square specimen of the solar cell. It can be seen that the mechanical properties of the material vary greatly in different directions. The tensile strength of the vertical battery strip decreases by nearly $50 \%$ compared with that of the parallel battery strip, while the ultimate strain of the vertical battery strip increases by nearly $50 \%$ compared with that of the parallel battery strip. This difference is mainly caused by the layout of the battery strip.

During the stretching process, the curve of output voltage of solar cell with strain and stress is shown in 


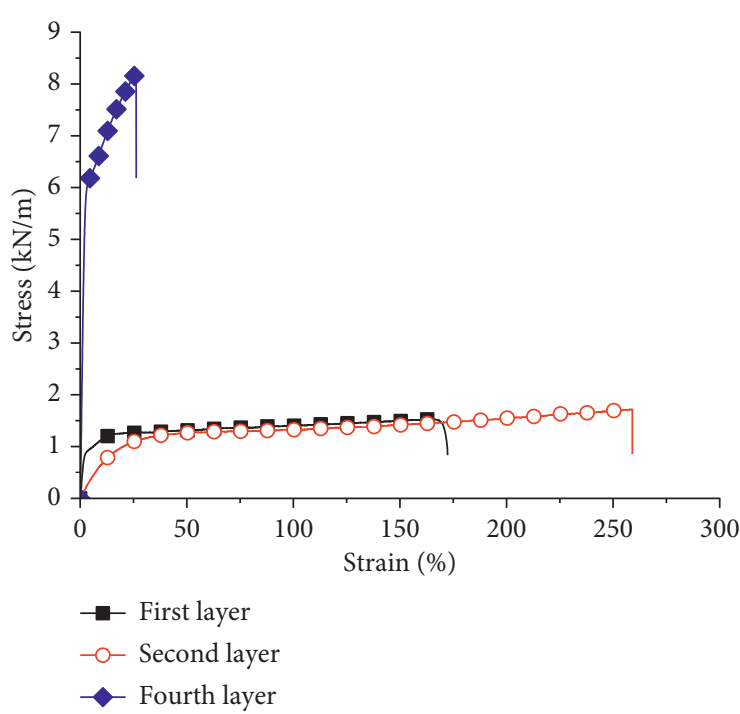

(a)

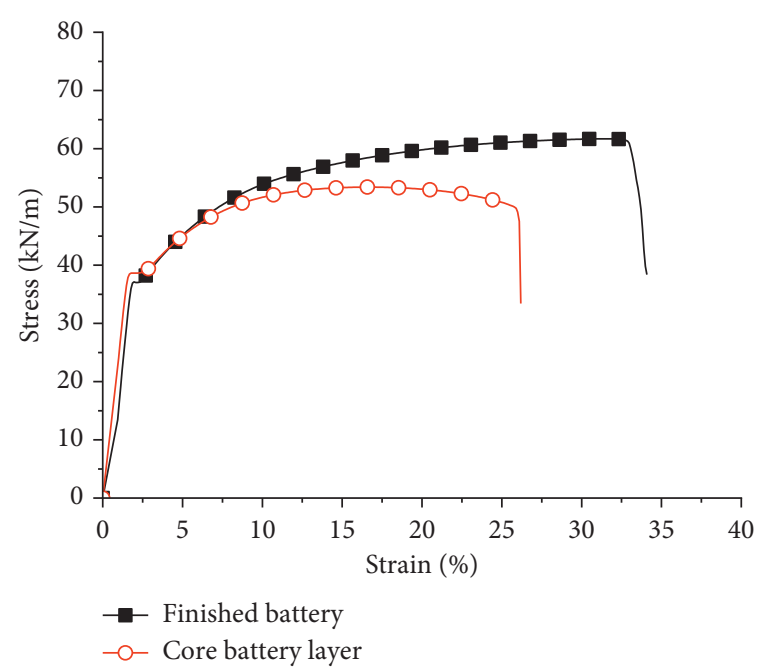

(b)

Figure 6: Tensile stress-strain curves of each layer of material. (a) The first, second, and fourth layers. (b) The third layer and finished product.

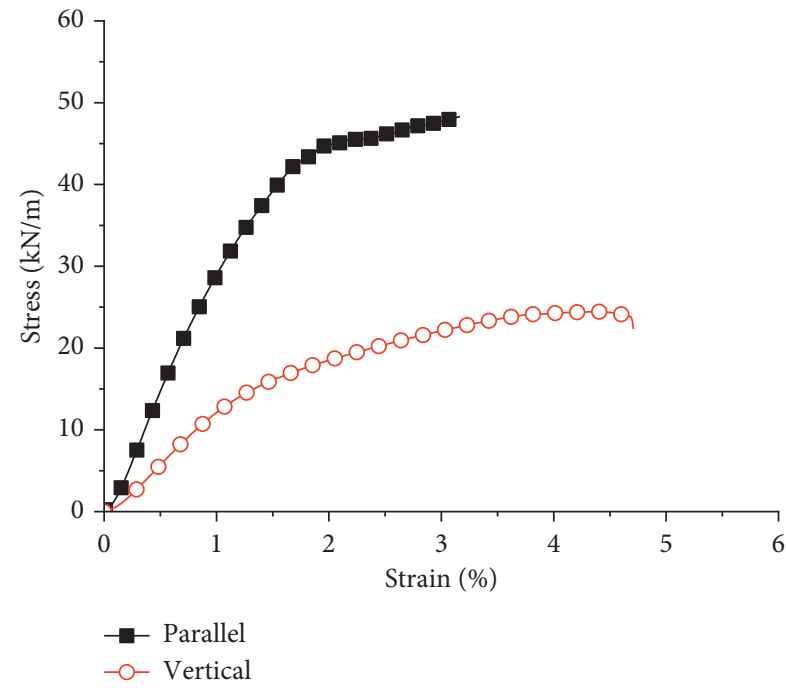

FIgURE 7: Tensile stress-strain curves of the square specimen.

Figure 8. It can be seen that the photoelectric performance of the battery is different when it is stretched in different directions. The output voltage of the battery remains stable when it is stretched along the direction of parallel battery strip. When the stress reaches $42 \mathrm{kN} / \mathrm{m}$ and the strain is $3 \%$, the connection part of the battery electrode is damaged and the output voltage drops to 0 . When stretching along the vertical direction of the battery strip, the output voltage of the battery also remains stable before the stress is $20 \mathrm{kN} / \mathrm{m}$. When the stress reaches $20 \mathrm{kN} / \mathrm{m}$, the output voltage of the battery starts to slowly decrease. When the stress reaches $23 \mathrm{kN} / \mathrm{m}$ and the strain reaches $4.5 \%$, the output voltage of the battery drops rapidly to 0 due to the tearing damage of the connection area of the battery strip. It can be seen that the output voltage curve of the solar cell has obvious drop point when it is stretched in two directions.
Figure 9 shows the stress-strain curve of PV-PVC composite and PVC membrane. It can be seen that the stress-strain curve of PV-PVC composite material can be divided into three stages. Firstly, the stress-strain curve is approximately linear in the stage of common stress. Secondly, this is the damage and failure stage of the bonding interface. With the increasing tensile force, the concentrated stress near the two ends of the solar cell becomes larger and larger. The bonding interface starts to damage from this position and gradually expands to the middle. The solar cells slip. Finally, this is the tension stage of membrane material. When the tensile force further increases to the whole bonding interface failure, the solar cell and the membrane material basically get separated. At this time, the membrane material alone bears the tensile force. In addition, the mechanical properties of PV-PVC composites show significant anisotropy. At $0^{\circ}$ (warp), the tensile strength is the highest, followed by $90^{\circ}$ (weft). At $45^{\circ}$, the ultimate strain is the highest and the tensile strength is the lowest. When deviating from the warp and weft directions $\left(0^{\circ}\right.$ and $\left.90^{\circ}\right)$ to $45^{\circ}$, the tensile strength of the material gradually decreases. The ultimate strain gradually increases. This change law is basically consistent with that of PVC membrane material.

Figures 10 and 11 show the curves of the output voltage of the PV-PVC composite strip specimen with the changes of strain and stress, respectively. It can be seen that the photoelectric performance of solar cells will change when they are stretched along different off-axis angles. It can be seen from the curve between the output voltage and the stress that the output voltage of the solar cell has an obvious voltage drop point. With the increase of the off-axis angle, the voltage drop is higher, and when the voltage drops, the critical stress value decreases. Within the stress range of common design strength $(16 \mathrm{kN} / \mathrm{m})$ of PVC membrane material, the drop of output voltage of solar cell is not more than $5 \%$. It can be seen that the flexible membrane solar cell 


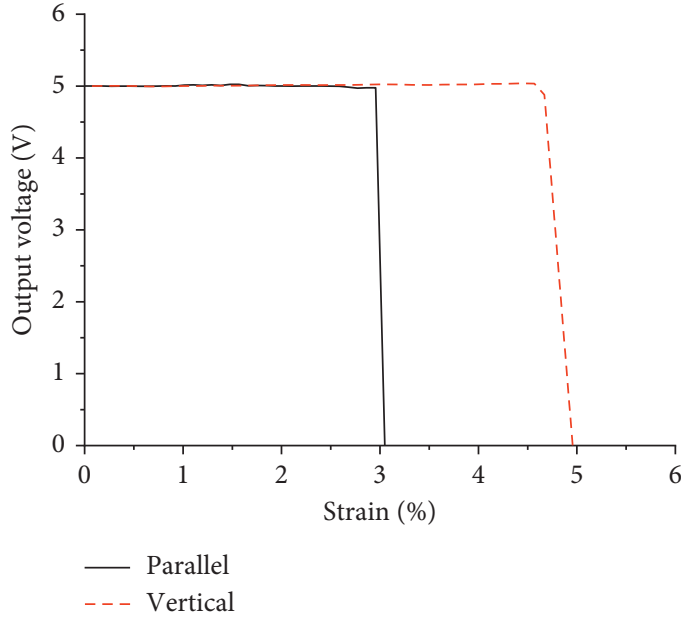

(a)

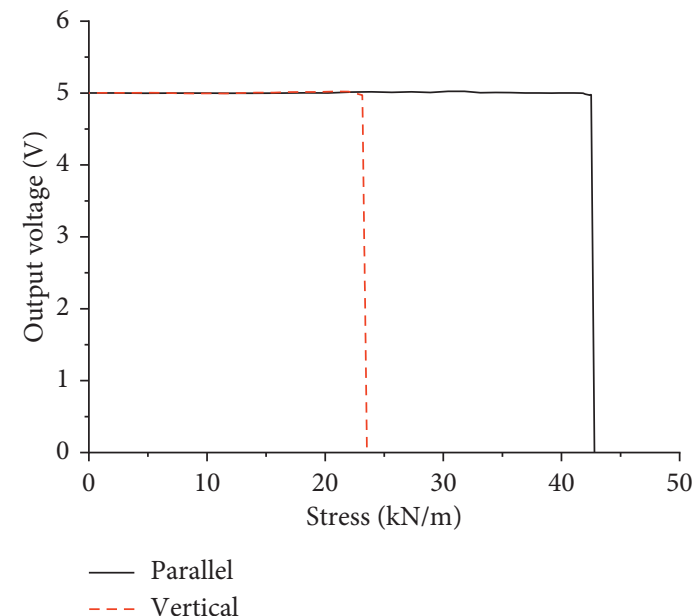

(b)

Figure 8: Output voltage curve of solar cells. (a) Output voltage-strain. (b) Output voltage-stress.

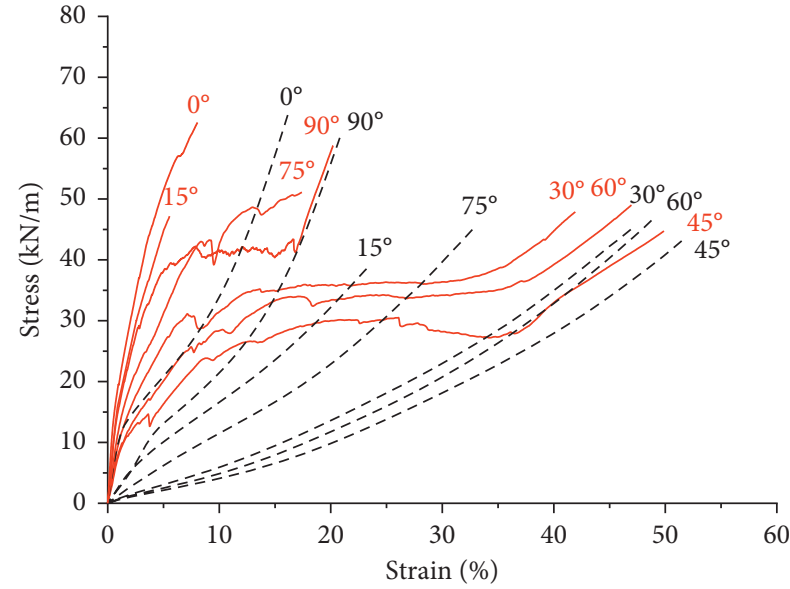

- PV-PVC composite

- - - PVC membrane material

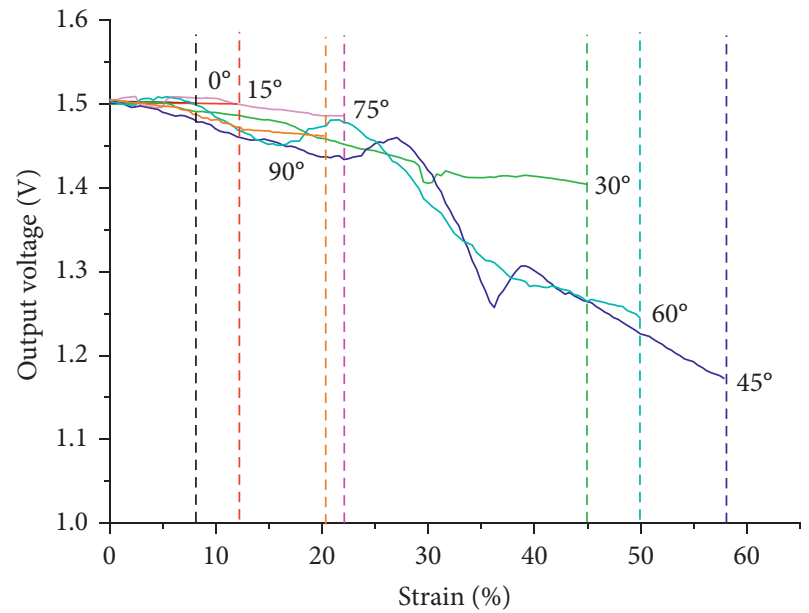

FIgURE 10: Output voltage-strain.

Figure 9: Tensile stress-strain curves of PV-PVC strip specimens.

in PV-PVC composite material can maintain high power generation efficiency in normal application.

The stress-strain curve of PV-PVC composite square specimen is shown in Figure 12. When stretching along the direction parallel to the battery strip, the three small battery strips bear the force together. The initial rigidity of the test piece is large, so the stress growth rate is fast. When the stress increases to a certain level, the solar cells and membrane begin to yield, and the rigidity of the specimen begins to decrease. After the yield stage, the specimen enters the stress strengthening stage. Since the membrane material restricts the lateral deformation of the solar cell through the bonding interface, there is no obvious necking stage and stress drop point. When stretched in the direction of the vertical battery bar, the specimen begins to be in a short linear phase. After passing the linear section, the rigidity of the specimen begins to decrease gradually until the specimen is broken. This is because the tensile strength of the material at the connection position of the small battery bar is lower when stretched in

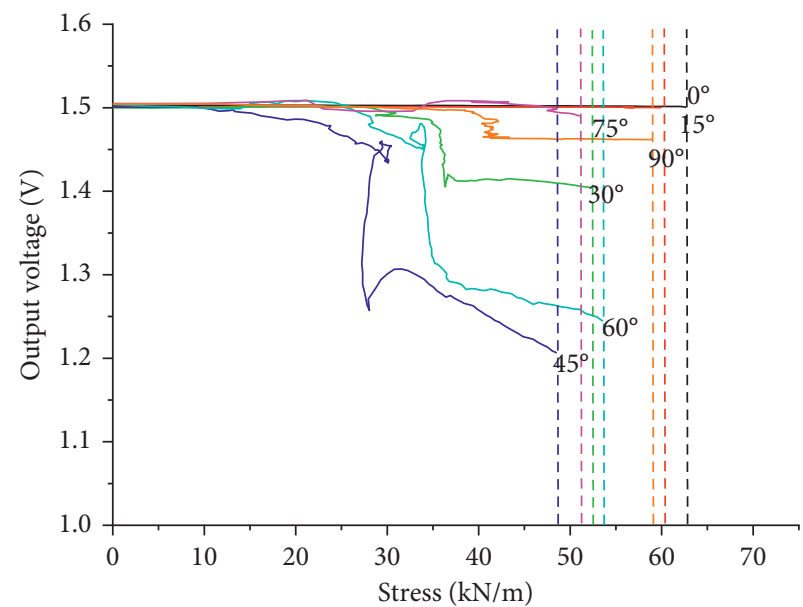

Figure 11: Output voltage-stress. 


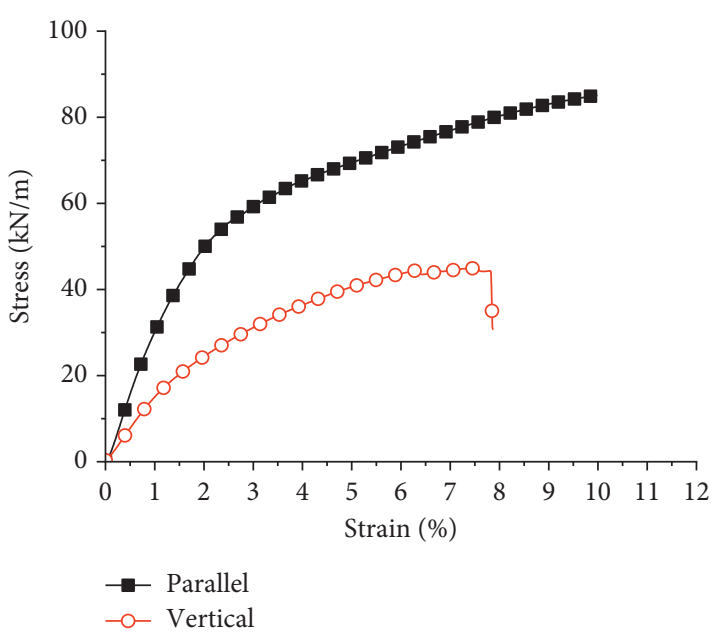

(a)

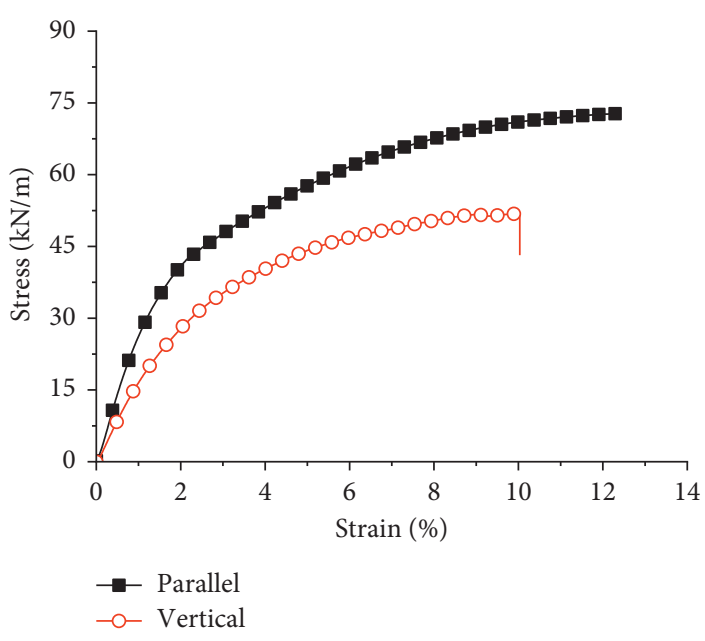

(b)

FIgURE 12: Tensile stress-strain curve of the square specimen. (a) Warp. (b) Weft.

the direction perpendicular to the battery bar. When the tensile force is transferred to the connection position, the material yields and the plastic strain increases rapidly. When the ultimate strain of the material is reached, the specimen will be broken at the connection position. The stress has a significant drop point.

Figures 13 and 14 show the relationship curves of the output voltage with the stress and strain of the square specimen of PV-PVC composite in different composite directions and tensile directions, respectively. The initial stiffness of the specimen is larger and the stress growth rate is faster when the specimen is stretched in the direction parallel to the battery strip. The output voltage starts to drop slowly until the connection between the conductor and the electrode is completely destroyed, and the output voltage drops to 0 . The output voltage of the solar cell is basically stable before reaching the limit strain when it is stretched along the direction perpendicular to the cell strip. Because the test piece is weak at the connection of the battery strip, the stress increases slowly when it is stretched along the direction perpendicular to the battery strip. When the connection position of the battery strip is torn, the circuit structure of the solar cell is destroyed.

3.1.2. Failure Mode. Figure 15 shows the failure mode of the long strip specimen of PV-PVC composite under different off-axis angles. According to the location of the failure, the failure modes of the specimen can be divided into three types. The first is the destruction of the PVC membrane. The second is the destruction of the bonding interface between the PVC membrane and the solar cell. The last is the destruction of solar cells.

The ultimate failure of the specimen is caused by the rupture of PVC membrane material. When the sample is stretched along different off-axis angles, there are certain differences in the form and degree of failure of the test specimen. By observing the fracture morphology analysis of the membrane material, it can be found that when the membrane material is stretched along the warp $\left(0^{\circ}\right)$ and the weft $\left(90^{\circ}\right)$, the test piece mainly bears the normal stress. The load is mainly borne by the base fabric. Eventually, the specimen was damaged because the fiber was broken by tension. The fracture of the specimen is flat and perpendicular to the tensile direction. When the tensile angle deviates from the warp and weft directions $\left(30^{\circ}\right.$ and $\left.60^{\circ}\right)$, the specimen is mainly subjected to large tensile stress and shear stress. The membrane material is damaged under the coupling action of tensile stress and shear stress. When the fiber is stretched in $45^{\circ}$ direction, the shear stress plays a leading role in the tensile process. The fibers on both sides of the specimen were pulled out of the coating under the action of shear stress. The two sides of the test specimen began to crack and quickly spread to the middle. When all the fibers in the section are broken, the fracture direction of the specimen is mostly perpendicular to the tensile direction.

Although the composite material is broken due to the normal stress when it is stretched along $0^{\circ}$ and $90^{\circ}$, the damage degree of the interface between the membrane material and the solar cell is quite different. It can be seen from the figure that the bonding interface at $0^{\circ}$ remains basically intact and the bonding interface at $90^{\circ}$ is completely damaged. When stretching along $0^{\circ}$, the membrane material is subject to the tension transmitted from both ends of the fixture, and the tension is transmitted to the solar cell through the bonding interface. The bond interface mainly bears the shear stress parallel to the interface. The shear resistance of the bond interface is sufficient, so the bonding interface is still intact before the membrane material is pulled. In addition, it is also found that after the damaged specimen is removed from the fixture, the specimen curls greatly. This is because during the stretching process, the membrane material and solar cell have relatively large stretching deformation along the stretching direction than the width direction. The plastic deformation of the membrane material is irrecoverable, while the stainless steel lining plate which determines the mechanical properties of the solar cell mainly undergoes elastic deformation. Due to the 


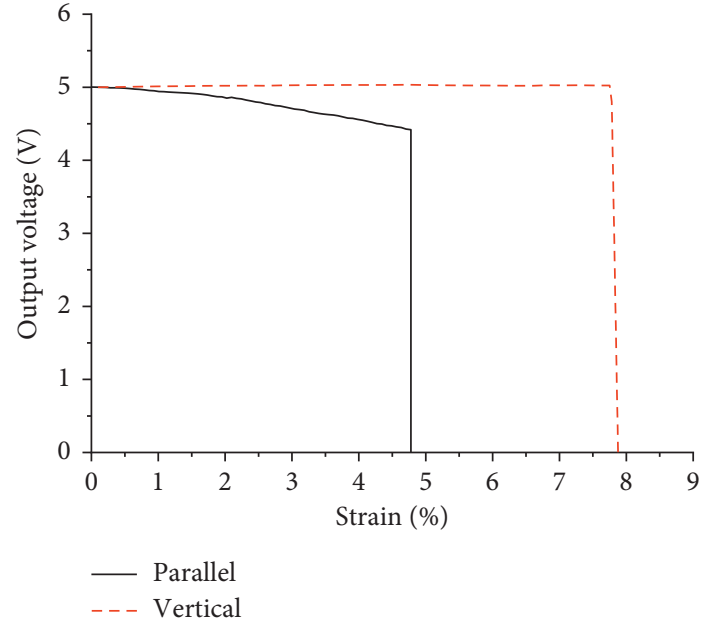

(a)

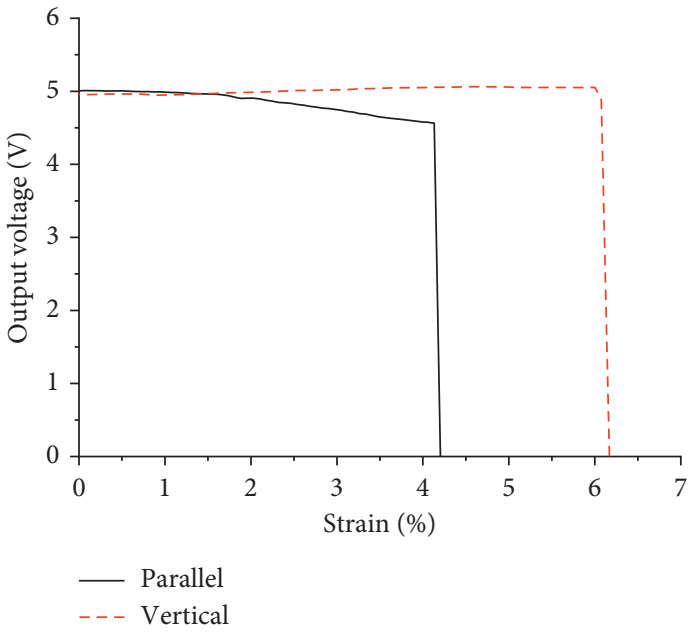

(b)

Figure 13: Output voltage-strain curves of the square specimen. (a) Warp. (b) Weft.

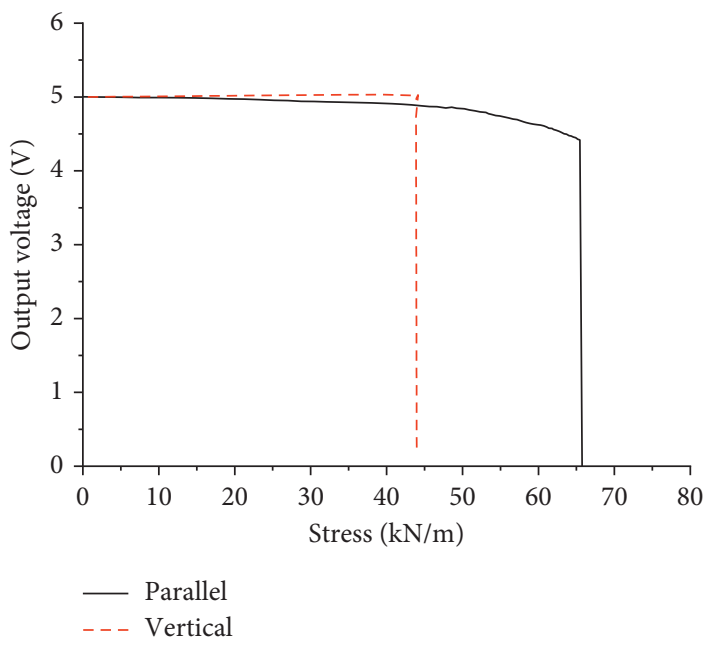

(a)

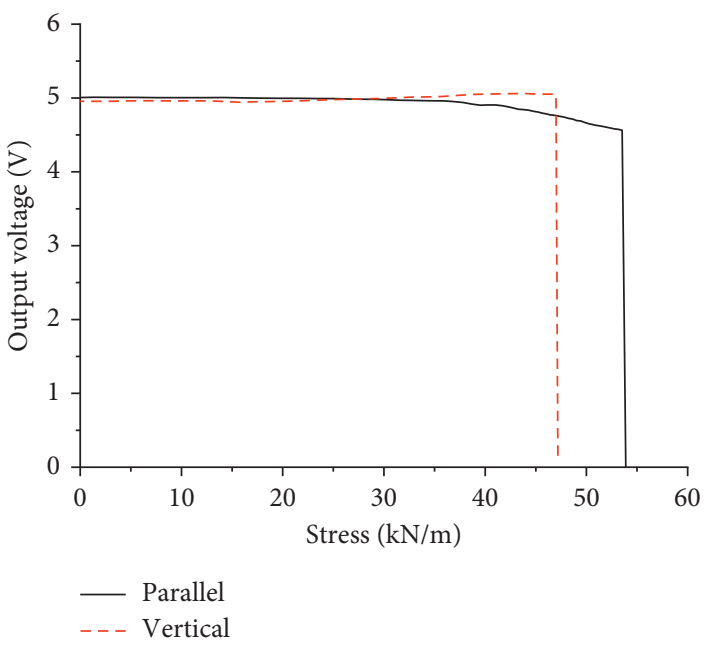

(b)

FIGURE 14: Output voltage-stress curve of the square specimen. (a) Warp. (b) Weft.

limitation of bonding interface after unloading, the deformation of stainless steel lining plate along the length direction cannot be recovered. This leads to the curling of the specimen along the length direction. When stretching along $90^{\circ}$, the weft fibers of the membrane are straightened from the bending state. The bond interface is mainly subjected to tensile stress perpendicular to the interface. The bonding area between the membrane material and the solar cell decreases gradually, which accelerates the destruction of the bonding interface until it is completely destroyed. When the solar cell is completely separated from the membrane, its elastic deformation can be restored. The specimen does not curl. When stretched along $15^{\circ}$ and $75^{\circ}$, there is a stress concentration at both ends of the solar cell, and the bonding interface in this area is partially damaged.
In the process of stretching along $30^{\circ}, 45^{\circ}$, and $60^{\circ}$, the fibers in the membrane not only tend to be straightened but also tend to be stretched. It leads to the greater torsion and tensile effects transferred to the bonding interface. This also further accelerates the failure rate of the bonding interface. During the stretching process, the solar cell is damaged by the stress transferred from the bonding interface. When the solar cell is stretched at a small angle away from the warp and weft, the solar cell is under a large tensile stress, which is obvious at the edge. This causes small vertical cracks to appear at the edge of the solar cell. When the specimen is stretched at a large angle away from the warp and weft, the specimen deflects greatly. The solar cell not only produces large cracks perpendicular to the tensile direction but also produces large bulges and twists outside the tensile plane. 


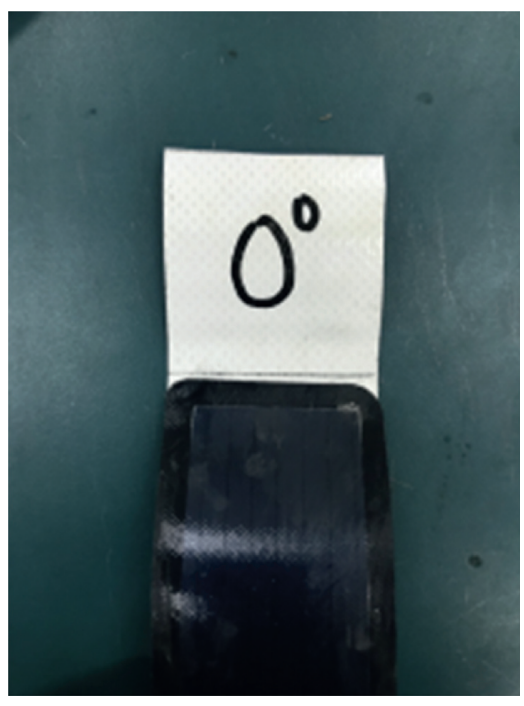

(a)

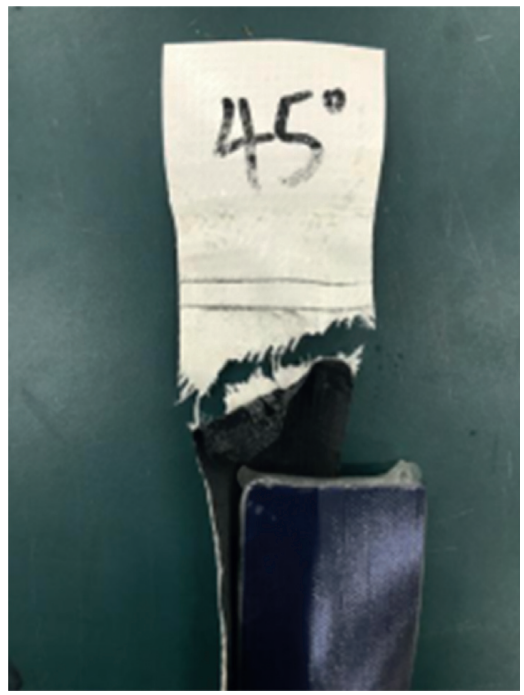

(d)

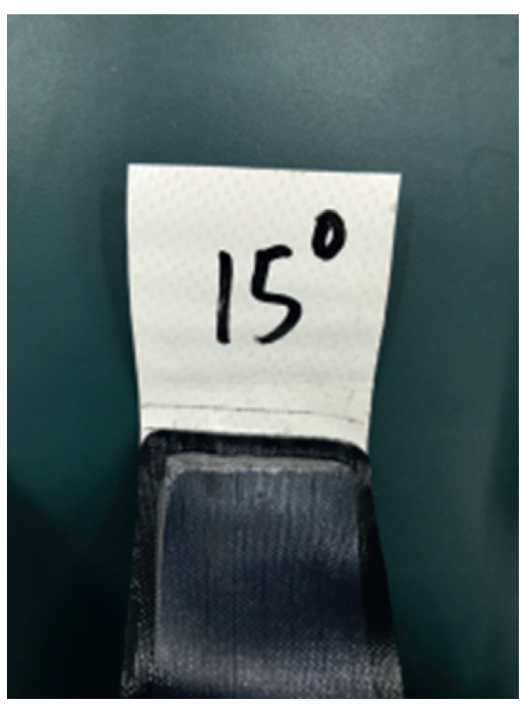

(b)

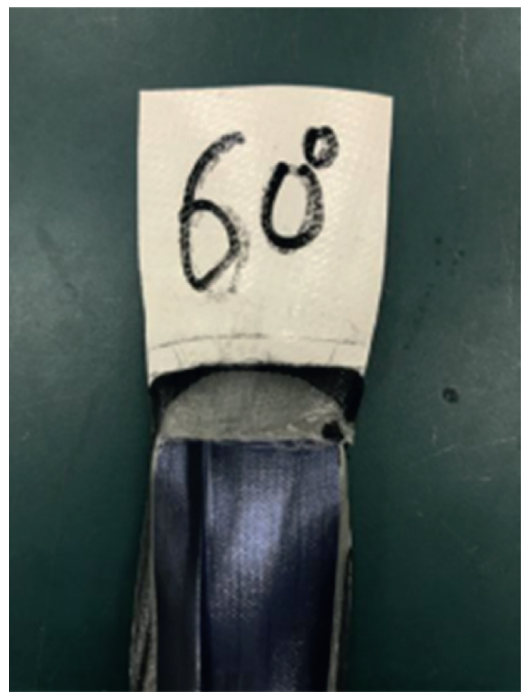

(e)

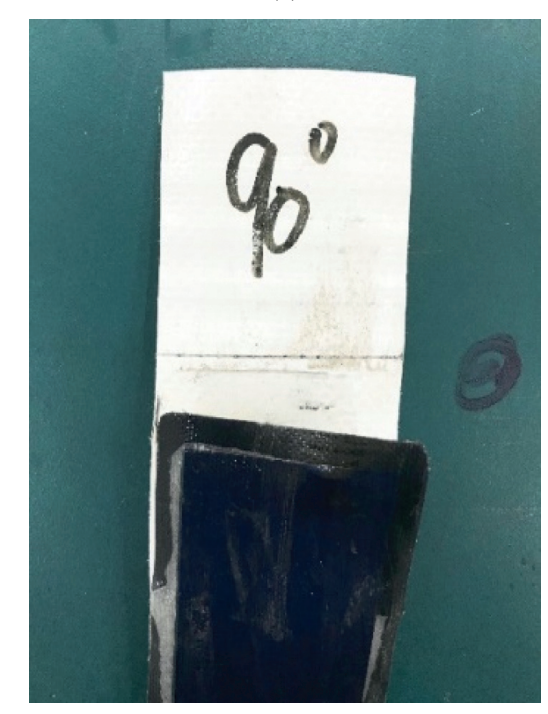

(g)

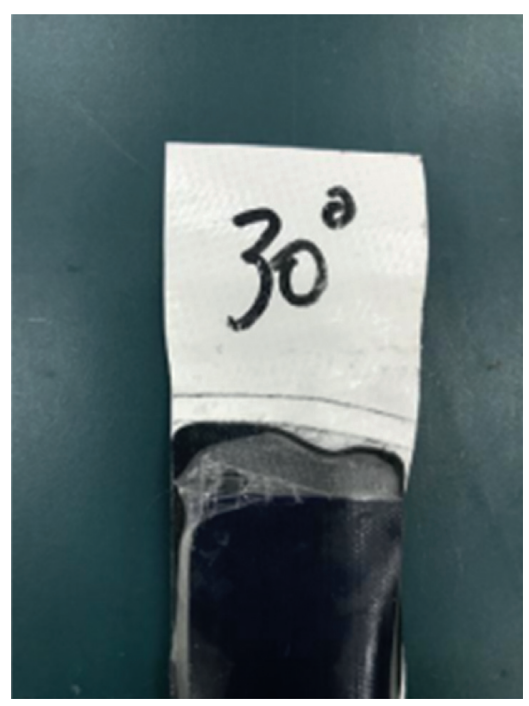

(c)

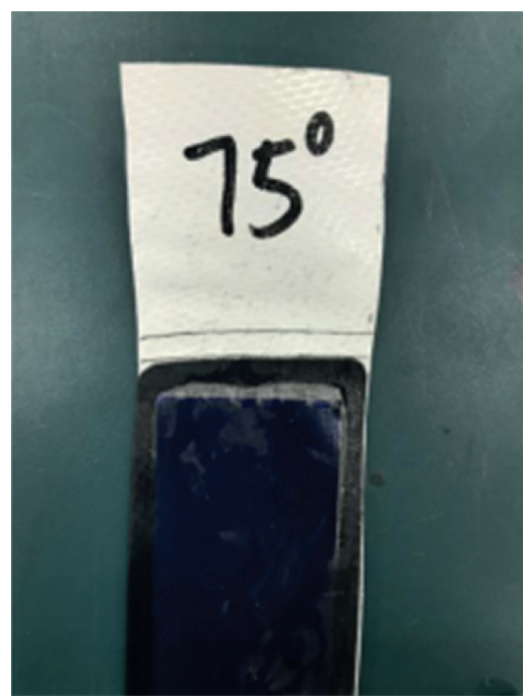

(f)

FIgURE 15: Failure modes of strip specimens. (a) $0^{\circ}$. (b) $15^{\circ}$. (c) $30^{\circ}$. (d) $45^{\circ}$. (e) $60^{\circ}$. (f) $75^{\circ}$. (g) $90^{\circ}$. 


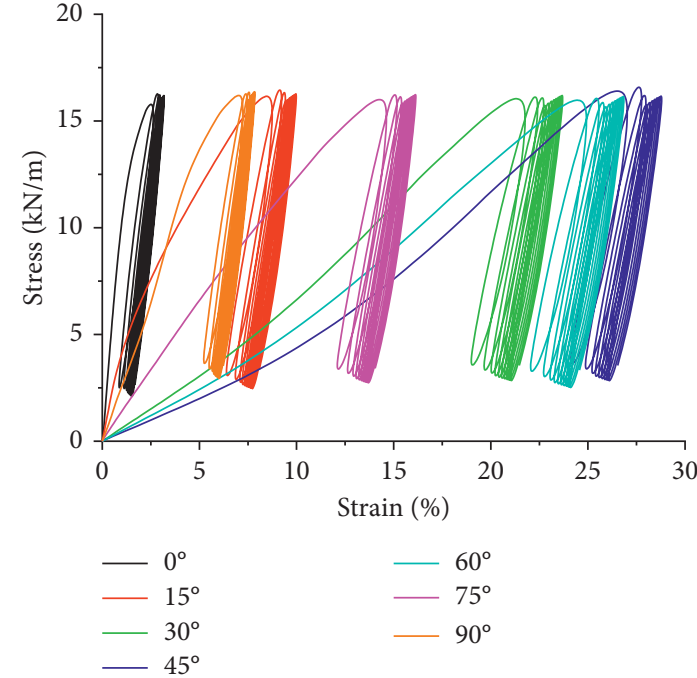

(a)

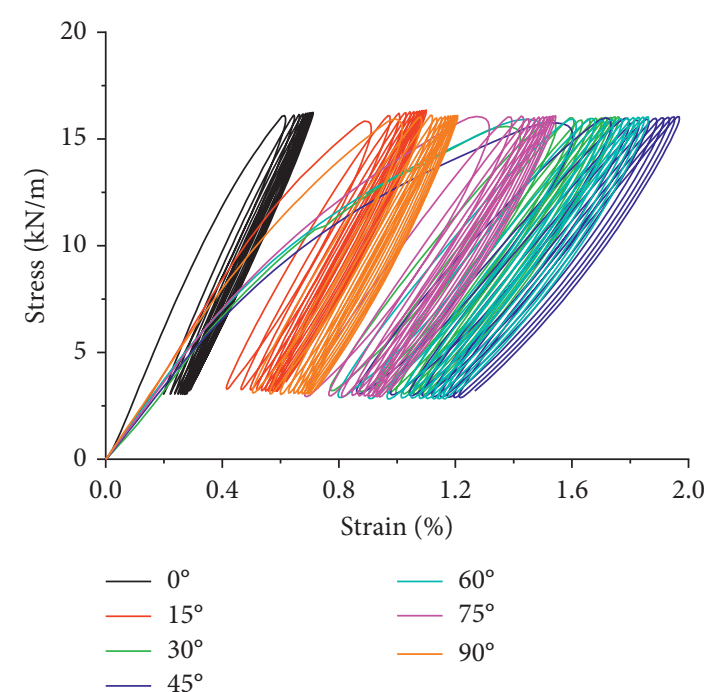

(b)

FIgure 16: Cyclic tensile stress-strain curve. (a) PVC membrane material. (b) PV-PVC composite.

The core layer of the battery is basically separated from the lower surface package layer.

3.2. Uniaxial Cyclic Tensile Test. The uniaxial cyclic tensile stress-strain curves of PVC membrane and PV-PVC composite are shown in Figure 16. It can be seen that the first loading curve and the subsequent unloading curve of PVPVC composite are not close. There is some residual deformation after unloading. Compared with the cyclic tensile curve of PVC membrane material, the difference is that the gap between the off-axis angle tensile curves of PV-PVC composite is obviously smaller than that of the PVC membrane. This is because the mechanical properties of the flexible thin-film solar cell composite with PVC membrane material have changed greatly. The first tensile curve of PVC membrane has obvious nonlinearity, while the nonlinearity of the first tensile curve of PV-PVC composite is obviously weakened. Especially in the $0^{\circ}$ direction (warp), the first loading curve and the subsequent loading curve basically coincide. For the first tensile curve with large off-axis angle, the stiffness of the material begins to decrease gradually after passing the initial linear section.

Figure 17 shows the distribution comparison of loading modulus of elasticity between PV-PVC composite and PVC membrane. It can be seen that the loading elastic modulus of the composite material is significantly larger than that of PVC membrane material. The distribution curve of loading modulus of elasticity of PV-PVC composite is fuller than that of PVC membrane. The difference of modulus of elasticity of PV-PVC composite at different off-axis angles is smaller, which indicates that the anisotropy of PV-PVC composite is weakened. This is because the stainless steel sheet of solar cell in PV-PVC composite material is isotropic.

The coated fabric membrane material is a typical viscoelastic plastic material. Under the cyclic loading, the internal damage and energy dissipation of the material will

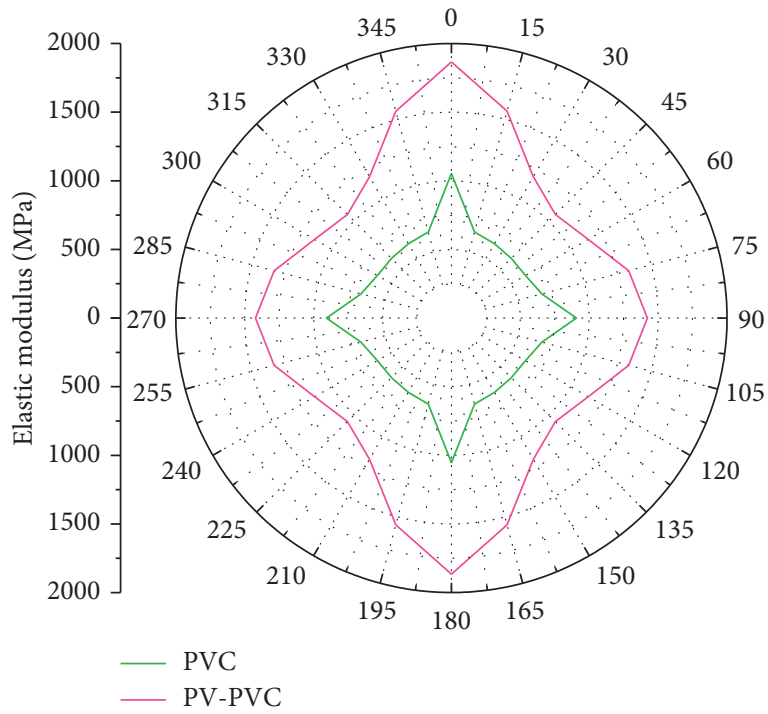

FIGURE 17: Elastic modulus of PV-PVC composite and PVC membrane.

occur, which lead to the unrecoverable residual deformation of the material after unloading. The relationship between the residual strain and cycle times of PVC membrane and PVPVC composite at different off-axis angles is shown in Figure 18. It can be seen that the curve of PV-PVC composite is similar to the residual strain curve of PVC membrane. The residual strain increases gradually, but the cumulative rate decreases and tends to be stable. The residual strain increases from $0^{\circ}$ to $45^{\circ}$. It can be found that the residual strain in different off-axis angles of PV-PVC composite is much smaller than that of PVC membrane.

During the cyclic loading of coated fabrics, the energy dissipation occurs due to the viscous effect. The loading curve and the unloading curve cannot overlap and form a hysteresis loop. Figure 19 shows the relationship between the 


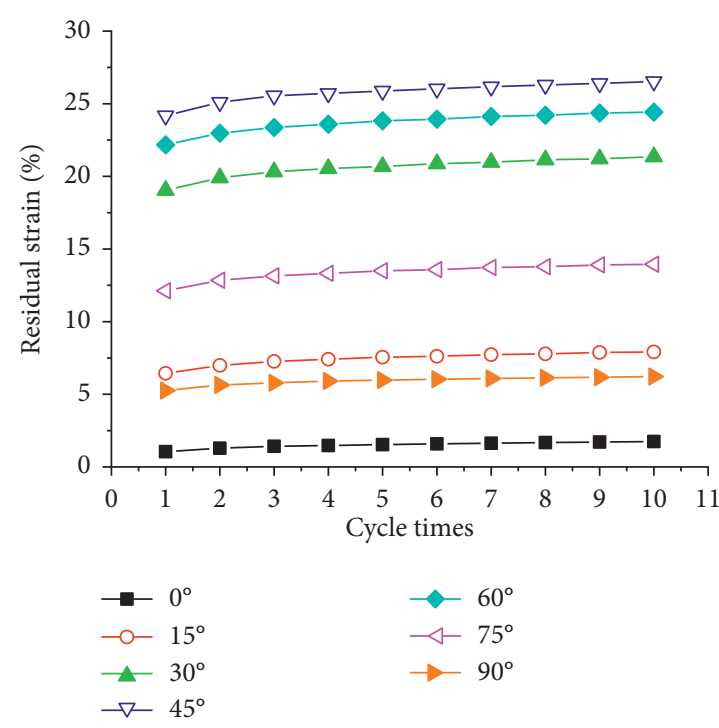

(a)

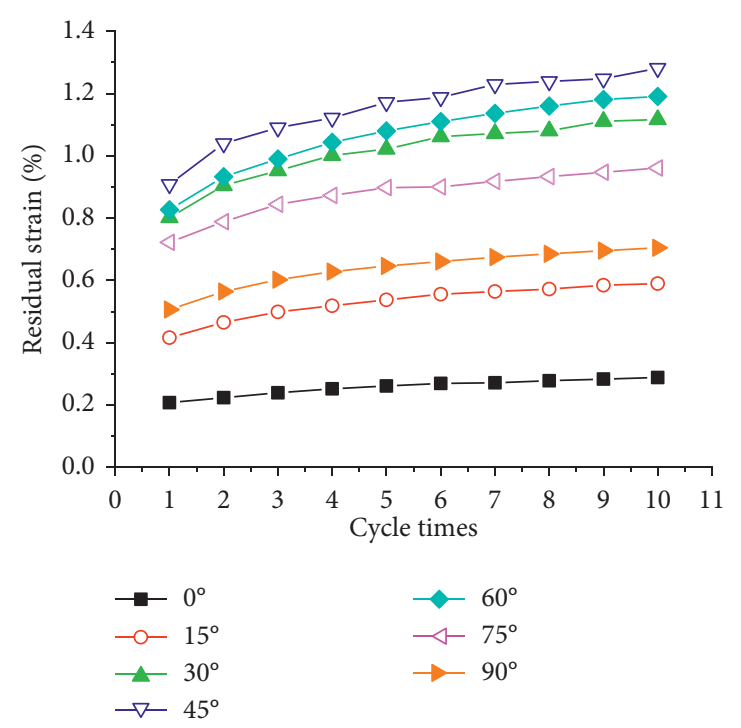

(b)

FIGURE 18: Relation between residual strain and cyclic times. (a) PVC membrane material. (b) PV-PVC composite.

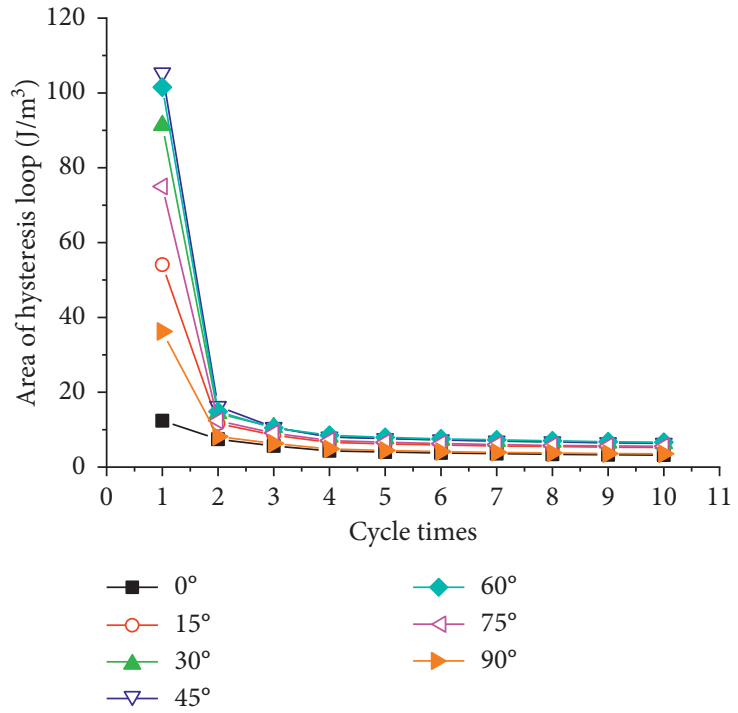

(a)

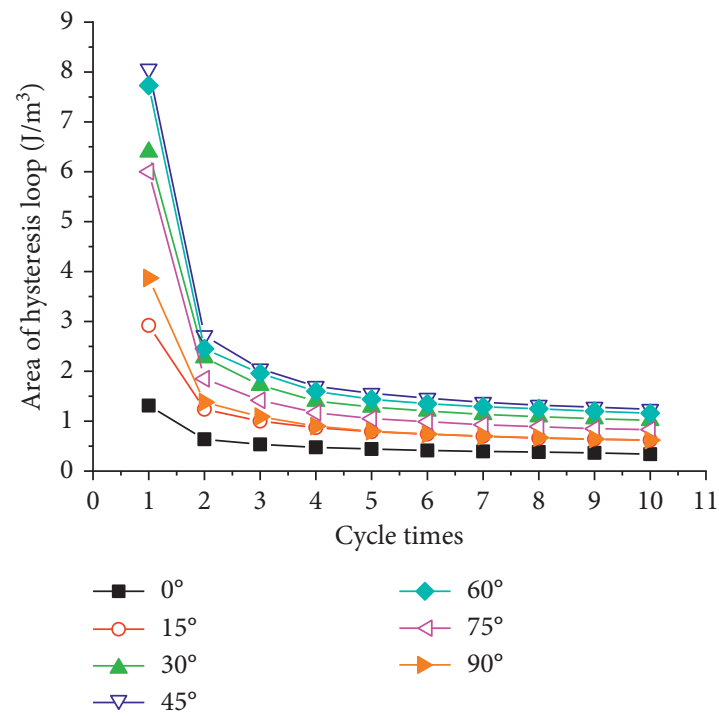

(b)

FIgURE 19: Relationship between the area of hysteresis loop and cyclic times. (a) PVC membrane material. (b) PV-PVC composite.

area of hysteresis loop and cycle times of PVC and PV-PVC composite specimens. It can be seen that the hysteresis area of PV-PVC composite decreases with the increase of the number of cycles, and the deceleration rate is gradually stable and tends to be constant. The hysteresis area of $0^{\circ}$ angle is the smallest, followed by $90^{\circ}$. With $45^{\circ}$ as the critical angle, the hysteresis area of other off-axis angles decreases with the increase of the deviation angle. After the first cycle, the hysteresis area of PV-PVC composite at $45^{\circ}$ is about $1 / 12$ of that of PVC membrane. While the hysteresis area of PVPVC composite is about $1 / 5$ of that of PVC membrane after the first cycle, 'the results show that irreversible damage has occurred in the interface between the membrane and the battery, which leads to a part of energy loss. The viscoelastic and plastic characteristics of the PV-PVC composite are weakened.

Figure 20 shows the output voltage versus strain curve of PV-PVC composite material specimens in different off-axis directions in the first three cycles. It can be seen that in the first loading process, the output voltage fluctuates slightly with the increase of strain and decreases slowly. While in the unloading process, the output voltage fluctuates slightly and remains stable basically. In the subsequent loading and unloading process, the output voltage changes in the same law. The magnitude of change is gradually reduced. This is because although the bonding interface between the 


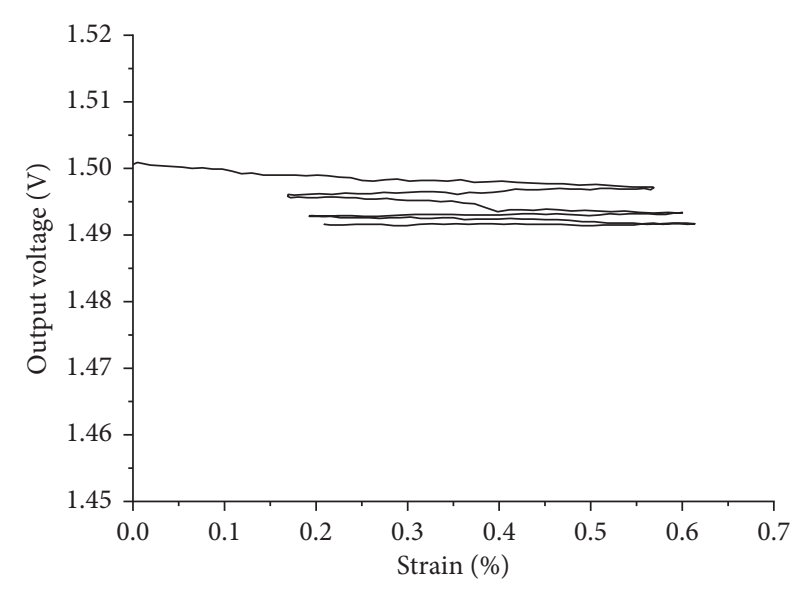

(a)

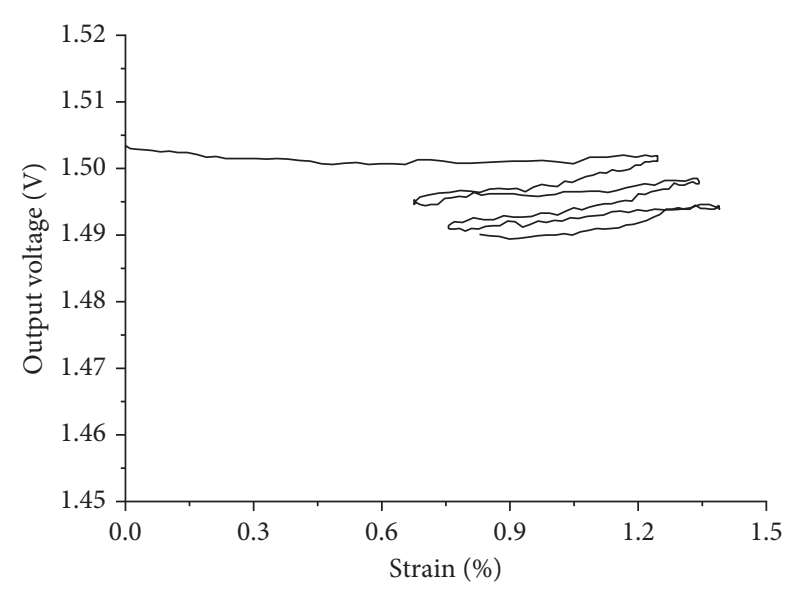

(b)

Figure 20: Voltage-strain curves of the first three cycles of PV-PVC composites. (a) Warp. (b) Weft.

membrane material and the battery does not have obvious damage during the loading process, there is a certain damage at the connection part between the battery electrode and the wire. This leads to fluctuations and drops in output voltage. With the increase of the number of cycles, the damage is basically saturated. The decreasing amplitude of the output voltage gradually decreases and tends to be stable.

\section{Conclusion}

In this paper, aiming at the design concept of photovoltaic integration of tension membrane structure, PVC membrane material and PV-PVC composite material were selected for the uniaxial tensile test and cyclic tensile test. The mechanical and electrical properties of PV-PVC composite were studied. The main conclusions are as follows:

(1) The stress-strain curve of PV-PVC composite can be divided into three stages. The first is the joint stress stage of the membrane and battery in the initial stage of stretching. The second is the damage and destruction stage of the interface between the membrane and the battery. The last is the uniaxial tension stage of the membrane. The tensile strength of PVPVC composite is similar to that of PVC membrane. With the increase of the deviation angle from the warp and weft, the difference of the ultimate strain between them is smaller.

(2) The output voltage of the solar cell in the long strip of PV-PVC composite decreases slowly with the increase of stress or strain. Within the stress range of the common design strength of PVC membrane material, the output voltage of solar cell can be reduced by no more than $5 \%$. It can meet the requirement that the solar cell can maintain good power generation efficiency in normal use.

(3) Compared with PVC membrane, the modulus of elasticity of PV-PVC composite under recycling load increased significantly. The residual strain and the area of hysteresis loop decreased significantly. The difference in mechanical properties of different offaxis angles is significantly reduced. As the off-axis angle increases, the decreasing rate and amplitude of output voltage gradually increase, but the maximum decrease is less than $1.6 \%$. Under the stress level of common design strength $(16 \mathrm{kN} / \mathrm{m})$ of PVC membrane material, solar cell can play a good photoelectric effect.

\section{Data Availability}

All data, models, and code generated or used during the study are included in the submitted article.

\section{Conflicts of Interest}

The authors declare no conflicts of interest.

\section{Acknowledgments}

This work was supported by the National Natural Science Foundation of China (no. 51678563), Jiangsu Vocational Institute of Architectural Technology (YJA317-06), Ministry of Housing and Urban-Rural Development of the People's Republic of China (2017-K1-002), and Jiangsu Provincial Department of Housing and Urban-Rural Development (2018ZD247).

\section{References}

[1] W. Han, G. Zhou, D. Gao et al., "Experimental analysis of the pore structure and fractal characteristics of different metamorphic coal based on mercury intrusion-nitrogen adsorption porosimetry," Powder Technology, vol. 362, pp. 386-398, 2020.

[2] W. Han, G. Zhou, Q. Zhang, H. Pan, and D. Liu, "Experimental study on modification of physicochemical characteristics of acidified coal by surfactants and ionic liquids," Fuel, vol. 266, Article ID 116996, 2020.

[3] N. Abas, A. Kalair, and N. Khan, "Review of fossil fuels and future energy technologies," Futures, vol. 69, pp. 31-49, 2015. 
[4] A. K. Shukla, K. Sudhakar, P. Baredar, and R. Mamat, "Solar PV and BIPV system: barrier, challenges and policy recommendation in India," Renewable and Sustainable Energy Reviews, vol. 82, pp. 3314-3322, 2018.

[5] A. K. Shukla, K. Sudhakar, P. Baredar, and R. Mamat, "BIPV based sustainable building in South Asian countries," Solar Energy, vol. 170, pp. 1162-1170, 2018.

[6] T. T. Chow, K. F. Fong, A. L. S. Chan, and Z. Lin, "Potential application of a centralized solar water-heating system for a high-rise residential building in Hong Kong," Applied Energy, vol. 83, no. 1, pp. 42-54, 2006.

[7] Í. P. dos Santos and R. Rüther, "The potential of buildingintegrated (BIPV) and building-applied photovoltaics (BAPV) in single-family, urban residences at low latitudes in Brazil," Energy and Buildings, vol. 50, no. 7, pp. 290-297, 2012.

[8] J. Liu, W. Aixiang, C. Liu et al., "Preparation and performance of $\mathrm{ZnO}-\mathrm{TiO}_{2}$ dye-sensitized solar cells," Journal of Composite Materials, vol. 28, no. 6, pp. 159-165, 2011.

[9] M. J. Sorgato, K. Schneider, and R. Rüther, "Technical and economic evaluation of thin-film CdTe building-integrated photovoltaics (BIPV) replacing façade and rooftop materials in office buildings in a warm and sunny climate," Renewable Energy, vol. 118, pp. 84-98, 2018.

[10] A. Shahsavar and Y. Rajabi, "Exergoeconomic and enviroeconomic study of an air based building integrated photovoltaic/thermal (BIPV/T) system," Energy, vol. 144, pp. 877-886, 2018.

[11] C. Ballif, L.-E. Perret-Aebi, S. Lufkin, and E. Rey, "Integrated thinking for photovoltaics in buildings," Nature Energy, vol. 3, no. 6, pp. 438-442, 2018.

[12] H. Wei, J. Liu, and B. Yang, "Cost-benefit comparison between domestic solar water heater (DSHW) and building integrated photovoltaic (BIPV) systems for households in urban China," Applied Energy, vol. 126, pp. 47-55, 2014.

[13] S. Shen and Y. Wu, "Structural morphology and modern spatial structure," Journal of Building Structures, vol. 35, no. 4, pp. 1-10, 2014, in Chinese.

[14] L. Tian, "70 years' achievements and prospects of China's spatial structure," Architectural Structure, vol. 49, no. 19, pp. 5-10, 2019.

[15] Q. Zhang, "Application review and future development of membrane structure in China," Architectural Structure, vol. 49, no. 19, pp. 55-64, 2019.

[16] J. R. Sheng and T. J. Zhang, "Research on light-duty and energy-saving characteristic of membrane structure and its development prospect," Advanced Materials Research, vol. 250-253, no. 1, pp. 925-930, 2011.

[17] R. Rüther and P. Braun, "Energetic contribution potential of building-integrated photovoltaics on airports in warm climates," Solar Energy, vol. 83, no. 10, pp. 1923-1931, 2009.

[18] J. Hu, W. Chen, Q. Cai et al., "Structural behavior of the PVETFE cushion roof," Thin-Walled Structures, vol. 101, pp. 169-180, 2016.

[19] Y. Zhang, J. Xue, Z. Lanlan et al., "Experimental study on the mechanical and electrical properties of flexible amorphous silicon PV and PVC membranes," Journal of Architectural Structure, vol. 39, no. 2, pp. 1000-6869, 2018, in Chinese.

[20] Y. Zhang, J. Xu, and Q. Zhang, "Advances in mechanical properties of coated fabrics in civil engineering," Journal of Industrial Textiles, vol. 48, no. 1, pp. 255-271, 2018.

[21] Y. Zhang, J. Xu, Y. Zhou, Q. Zhang, and F. Wu, "Central tearing behaviors of PVC coated fabrics with initial notch," Composite Structures, vol. 208, pp. 618-633, 2019. 